DOI: $10.24193 /$ tras.62E.1

Published First Online: 02/25/2021

\title{
PUBLIC MEASURES TO DEAL \\ WITH THE NEGATIVE EFFECTS \\ OF INTRA-EU MIGRATION. CASE STUDY: \\ SUCEAVA COUNTY, ROMANIA
}

\section{Delia Cristina BALABAN}

Viviana HUȚULEAC

Romania is one of the EU member states reported to have a high rate of intra-EU migration. There is a temporary labor migration, but also Romanian migrants decide to leave their country for good. This phenomenon has a large economic, cultural, and social impact on society, with the northeastern region of Romania being especially affected. The main objectives of the present research are: (1) to analyze the social measures applied by the local authorities, especially the County Council and DGASPC (Social Work and Child Protection Services) Suceava to strengthen the ties with the diaspora, and to deal with the problem of the children with one or both parents working abroad, and (2) to determine how the local public authorities communicated on this issue. The applied research methods are document analysis, content analysis of the social media accounts of the above-mentioned institutions, and local media, as well as in-depth interviews that were conducted at the Suceava County Council and the Social Work and Child Protection Services.

Our findings underlined that Suceava county has a defined strategy to deal with the negative effects of the labor migration phenomenon related to the phenomenon of the children left at home, there was a constant preoccupation during the analyzed period to communicate on this subject and even more, the local authorities took some measures to deal with this relevant issue. As both local authorities and local media acknowledged, more social measures are still needed.

Keywords: intra-EU migration, social policies, child protection, regional development, qualitative methods.

\section{Delia Cristina BALABAN (corresponding author)}

Professor, Department of Communication, Public Relations and Advertising, Faculty of Political, Administrative and Communication Sciences, Babes-Bolyai University, Cluj-Napoca, Romania Tel.: 0040-264-431-505

E-mail: balaban@fspac.ro

\section{Viviana HUȚULEAC}

PhD candidate, Doctoral School of Communication, Public Relations and Advertising, Faculty of Political, Administrative and Communication Sciences, Babes-Bolyai University, Cluj-Napoca, Romania E-mail: viviana.hutuleac@fspac.ro 


\section{Introduction}

Romania is one of the EU member states reported to have a high rate of intra-EU migration. This phenomenon started even before 2007, the year of Romania's accession to the EU, and intensified in the following years. In 2017, Romanians together with Germans, Italians, Polish, and Portuguese made up more than half of all movers in the EU-28/EFTA region with 6.6 million people (OECD, 2018, p. 25). According to Eurostat, Romanians have built the largest community of EU-born immigrants $(1,024,800)$, followed by Germans $(211,600)$ (Eurostat, 2017). Only recently, starting in 2015, Romania reported a positive net migration three years in a row, with citizens from Moldova, Turkey, China, Syria, Israel, and other EU countries such as Italy, Germany, France, Hungary, and Greece moving to Romania.

There is a temporary labor migration, but also Romanian migrants decide to leave their country for good. The model of the traditional long-term migrant (Eisenstadt, 1953) becoming more and more integrated into the destination country with weaker ties to the country of origin is no longer suitable for the current situation. The intra-EU migration includes short-time working or studying migration, cross-border commuting, seasonal migration (Peixoto, 2001). Thus, in some families one or both parents are abroad, working for several months or sometimes for years and their children are left in the care of their grandparents or other close relatives. This phenomenon has a large economic, cultural, and social impact on society, with the northeastern region of Romania being especially affected. The county of Suceava is the second largest in Romania in terms of population but occupies the first position regarding the number of people that are working abroad, about $20 \%$ of its total population.

We aimed to develop an in-depth approach to define the relationship between local authorities from a county that is still confronted with the above-mentioned situation from the perspective of dealing with issues related to the left at home children of the temporary and long- time migrants. The present research focused on how local authorities such as the County Council of Suceava and Social Work and Child Protection Services Suceava deal with the issue of the children left at home without parents, but with their grandparents or other caregivers. We examine the policies and practices of the local authorities in this particular Romanian county that faced large scale intra-EU migration of their labor force. We aimed to identify best practices but also to formulate recommendations for policymakers. The main objectives of the present research are to analyze the social measures applied by the local authorities, especially the County Council and Social Work and Child Protection Services to strengthen the ties with the diaspora, and to deal with the problem of the children with one or both parents working abroad and, secondly, to determine how the local authorities communicated on this issue, as scholars in the field underlined the role of communication to develop a strong relationship with the Romanian communities abroad.

The present paper was elaborated in five sections. After underlining the context and the relevance of the research in the introduction we looked in the second section 
at the development of the Romanian intra-EU migration in the last 30 years focusing on the social impact of the phenomenon and especially on the issue of the children left at home. A literature review of migration and return migration theories where we look in particular at the best practices of local and national public institutions in building a strong relation to the diaspora for the benefit of the home communities was undertaken in the third section. Research objective and research questions, data collection, content analysis, and in-depth interviews are derived in the fourth section. Findings and their interpretation followed in the fifth part. The final section is dedicated to the conclusions with a focus on the relevance of our findings for other EU regions that faced the phenomenon we analyzed and on recommendations for local authorities and policymakers at the national level.

\section{Intra-EU migration of Romanians and its social impact: children left at home}

Migration is not a new phenomenon for Romania. It also existed before 1989, especially the migration of the population between regions in Romania or of ethnic minorities such as Germans, Hungarians, and Jews who left the country during the Communist regime (Diminescu, 2009; Șerban and Voicu, 2010). During the so-called 'transition' that took place in the 1990s, Romania was one of the countries from Eastern Europe that was confronted with a large emigration towards EU member states such as Italy, Spain, France, Germany, and the United Kingdom. Sandu (2006) emphasized the relevant role of migration for the Romanian transition, even calling it the 'third post-communist transition path' beside the economic and political transition. Migration is part of social transition and it has a spontaneous character.

In the 1990s, a significant number of Romanians migrated to southern European countries such as Italy and Spain driven by the high demand for a low-skilled workforce. Even in the period before Romania's accession to the EU, specific bilateral agreements between Italy and Romania and several rounds of regulation facilitated the predominantly female working movements towards Italy (Popescu, 2008). Existing networks played an important role in the choice of location and in finding employment (Mara, 2012). Another important pull factor was the agencies for labor recruitment, part of a 'complex governance structure of labor flows between Romania and Italy' (Ban, 2012, p. 11). Spain was a popular destination during the 1990s when Romanians needed a visa to travel to this country due to its relatively higher tolerance for illegal migrants and seasonal work (Stanek, 2009; Vîrga and Iliescu, 2017). The regulation processes implemented by the Spanish government in 2000-2001 and 2004, eliminating visa obligations for traveling in 2002, and Romania's accession to the EU (2007), were important elements related to Romanian's migrations to Spain (Șerban and Voicu, 2010; Ciornei, 2016). Between 2007 and 2009, Spain required applications for working visas for Romanians, except for self-employed migrants. Until 2010, Italy and Spain were the main destination countries for Romanian migrants, 
the majority working in agriculture and the construction sector (Jobelius and Stoiciu, 2014; Hanganu, Humpert and Kohls, 2014; Ricci, 2015).

The main reasons to migrate to Spain and Italy were economic, i.e. the search for better job opportunities, for financial resources to build a house in their hometown or village, to buy land in Romania, or to pay for their children's education at home. They often accepted unpleasant conditions on the unregulated market to earn a higher income than they would have secured in their home countries (Bleahu, 2007). According to the results of field research, return motivations such as family-related considerations, emotional attachments to the country of origin, as well as a lack of integration or sense of belonging to the host country were also taken into consideration by Romanian migrants, building a so-called 'back-and-forth' circular pattern of migration (Marcu, 2011).

The economic crisis and the slow economic recovery that followed contributed to a decrease in the migration flow from Romania towards Italy and Spain (Bertoli, Brücker and Moraga, 2013). The peak of return mobility from Spain to Romania was reached in 2012 when Romanians who had already settled in Italy or Spain relocated to other EU countries such as Germany or the United Kingdom. During 2014 and 2015 Romania ranked second after Poland as the EU country of origin with the largest number of immigrants working in the UK. According to OECD (2017) in 2015, Romanians $(221,400)$ made up the largest inflows of foreign European nationals migrating to Germany. Compared to Spain or Italy, Germany has attracted a large number of highly skilled workers from Romania, the share of academics being on average 3\% higher than the share of academics among Germans without any migration background (Hanganu, Humpert and Kohls, 2014; Engler and Weinmann, 2015). A special case in the recent history of Romanian migration to other EU countries is the migration of physicians, which has a large impact on the Romanian healthcare system that has been constantly rated as poor or even the poorest among EU member states; France is one of the main destinations for this type of highly educated migrants (Saghin, Lucheș and Marici, 2016).

Besides the positive effects on economic status improvement, labor mobility also has negative effects on Romania. In terms of demographics, Romania's population has decreased since 1990 and the demographic potential has also decreased because of the children that migrated with their parents, the loss of labor force potential, the deficit in the labor market (in constructions, healthcare, ITCs, etc.), an increased numerical and structural employment deficit (Vasile et al., 2013). Social problems in the country of origin are complex. Often children grow up with one parent, with grandparents, or other caregivers. Thus, they are affected by the negative consequences of migration. Even if they have a higher economic status than their peers in school, migrant children left at home are often confronted with problems at school (dropout, juvenile delinquency), with psychological insecurity or anxiety. The elderly population left in home communities faces specific problems as well (Sandu, 2009; 2010). Deciding to leave the children at home with their grandparents or other caregivers is 
part of a complex decision-making process. Large numbers of EU-migrants coming from Suceava decided not to take their children with them, this proved to be at this time a phenomenon with a large impact on local communities. The opposite solution was adopted by Polish migrants even from small rural communities who preferred to take their children with them (White, 2019).

According to the official data provided by Social Work and Child Protection Services at the end of 2017, about 95,000 children were registered to have at least one parent working abroad and about 18,000 children had both parents working abroad. The Romanian Ministry of Foreign Affairs reported even higher figures: 150,000 children that had at least one parent working abroad at the beginning of the year 2018 (Digi24.ro, 2017; presidency.ro, 2018). The differences occurred because not every parent that worked abroad reported the situation of their child or children to the authorities even if the Romanian law requires it.

The northeastern part of Romania, one of the poorest regions in the EU, is especially affected by the consequences of this working migration phenomenon, which has raised concerns at the level of the local and national authorities. The official data from the Romanian Social Work and Child Protection Services mentioned 31,391 children from the northeastern region that had at least one parent working abroad in 2018 (presidency.ro, 2018).

Suceava is the second-largest county in Romania but occupies the first position regarding the number of people that have left to work abroad. 140,000 people have left to find a better job abroad, which accounts for $20 \%$ of the total population of the county. According to the latest statistics of the General Directorate of Social Work and Child Protection Services Suceava, at the end of the third trimester of 2018, there were 8,476 children from 6,096 families in Suceava County with parents working abroad. Some of the parents work abroad only a few months each year, others for several years.

Under these circumstances, building social ties between diaspora and the country of origin is more than welcome especially in the particular situation of Romania. Until 2012 this element was underdeveloped in terms of economic and social sustainable cooperation (Vasile, 2014).

\section{A multi-level approach in dealing with the negative effects of the intra-EU migration in the home countries}

As the model of the traditional long-term migrant (Eisenstadt, 1953) does not apply to the current situation, the importance of return migration becomes more and more relevant. According to the New Economics of Labor Migration Theory, the focus shifted from the individual independence of the migrant to the mutual interdependence between migrants and the communities they are coming from. In this context returning home has become a success story. Migrants have their goals abroad such as receiving high income and accumulate savings, but their role for their communities of origin is far beyond. The structural approach to return migration underlined the 
impact of the returning migrant on their origin communities, of their impact on their home countries, not only from an economic point of view but also for social change (Casarino, 2004).

In the last years, in some European countries, public policies and actions regarding intra-EU migration effects in the home countries have moved from a top-down centralist perspective to a multi-level governance model. A multi-level model includes the local or the regional levels, the national and the EU-levels becoming more and more relevant (van Ostaijen and Scholten, 2018). The local level with municipalities as independent actors is a key element of a successful approach. Local authorities developed various strategies to influence key policymakers and emphasized the state-social partners' relations in the relationship with the labor migrants and the issues of their families. There are cities with a more culturalist approach and cities with a more socio-economic approach to integrating migration (Alexander, 2007). Unfortunately, in some EU-migration home countries there is a lack of sufficient funding that would allow the development of larger projects in this field (Pawlak, 2015).

Previous scholarship in the field underlined the positive effects of emigration on the home countries from the perspective of institutional development, if migrant's destination countries are democratic, which is the case with intra-EU migration. Improving political institutions, transferring new ideas and political norms, circular remittances are the main aspects that were mentioned as positive effects for the home countries (Lodigiani, 2016). Studies on return migration in Eastern Europe emphasized the role of returning migrants as agents of change, as contributors to the return of innovation in countries such as Latvia (Lulle, Krisjane and Bauls, 2019). Social remittances (Levitt, 1998) in the form of transmission of ideas, values, and practices contributed to local cultural change following migration and return migration in small Polish communities (White, 2019). Social remittances influenced cultural transformation in the home countries, while maintaining a social connection with the help of communication was crucial for the relationship between home communities and migrants.

Previous literature dealt with the effects of intra-EU migration focused on Poland which is to some extent similar to Romania in terms of the significant migration after the country became an EU member state in 2004. In 2012 the Government developed the Poland Migration Policy, a legal framework that aimed to minimize the effects of migration by focusing on systematic solutions, especially concerning assistance to returnees and monitoring the emigration in Poland. Similar to Romania, migration impacted in different degrees the Polish regions. Like in the case of Suceava county in Romania, the Polish Opolskie region was especially affected by the emigration phenomenon, being called the 'full-euro-orphanage' because of the high numbers of families where parents worked abroad and children were left at home with early caregivers. A multi-governance approach was implemented to deal with this phenomenon. In 2008, within the Polish Ministry of Foreign Affair, an interdepartmental working group on return migration was founded. Polish regional authorities faced 
demographic changes and other effects related to the regional development, as a consequence of the emigration. Local authorities faced substantial financial strains, on one hand, working migrants were paying taxes abroad and, on the other hand, the education and the healthcare and social services were provided by the public budgets of their home communities. The Opolskie region was in particular affected by the phenomenon of the left at home children. Regional strategies to respond to this phenomenon were developed focusing on a civil-society centric approach in terms of implementation of activities and accessing EU funding (Kindler, 2018). Overall, the Polish case underlined the idea that the key to the local success in building new organizations and businesses is maintaining strong transnational links with intra-EU migrants even after their return (White, 2019).

Within the perspective of governance approaches and policy networks in these multi-level settings (van Ostaijen and Scholten, 2018), our study focused on Suceava local authorities, their interaction with the social actors, with NGOs, the relationship with the national level in dealing with the negative effects of the children left at home by intra-EU working migrants. We intend to identify elements of a bottom-up approach (van Ostaijen and Scholten, 2018) with local authorities being active in agenda setting on this issue and in formulating policy solutions. Best practices in form of projects, initiatives, and activities focusing on dealing with the negative effects of emigration such as the left at home children from the county of Suceava that proved to be effective and transferable are the focus of the present study. In line with the multi-level governance approach (van Ostaijen and Scholten, 2018) on intra-EU migration, best practices of local authorities have to include the implementation of activities by civil society.

\section{Data and methods}

The main objective of the present research is to analyze the social measures applied by local authorities in Suceava to strengthen ties with the intra-EU working migrants and the diaspora and to deal with the problem of the children with one or both parents working abroad. Our research questions are:

- Q1. What are the policies and best practices of the County Council of Suceava and of the General Directorate of Social Work and Child Protection Services Suceava to strengthen the ties with the Romanians working abroad?

- Q2. What are the policies and best practices of the above-mentioned institutions dealing with the issue of the children left at home as a consequence or the largescale migration?

- Q3. How those issues were communicated on social media and in the local media?

The research methods are document and content analysis, as well as in-depth interviews that were conducted at the County Council of Suceava and the General Directorate of Social Work and Child Protection Services Suceava. The documents that we analyzed included the guide that was developed by the General Directorate of 
Social Work and Child Protection Services Suceava for parents working abroad and several messages of the president of the County Council Suceava related to diaspora, posted on the special section of the official website ${ }^{1}$ of the institution. Simultaneously, we carried out the content analysis of the Facebook posts of the page 'Relationship with Diaspora', an official social media page developed by the local authorities from Suceava County and dedicated to the Romanian migrants, between May 1, 2018, and January 20, 2019. Besides that, we conducted a content analysis of the local media coverage of the main activities of the Suceava County Council between August 1, 2018, and August 30, 2018, the month dedicated to the events related to diaspora. The online publications: monitorulsv.ro, crainou.ro, obiectivdesuceava.ro, newsbucovina. ro, zorilebucovinei.ro were analyzed. Finally, we conducted four in-depth interviews with four representatives of the above-mentioned local authorities; the interviews lasted between 60 and 80 minutes.

\section{Research results}

At the county level, the two main public authorities that developed initiatives related to our researched topic are the County Council of Suceava and the General Directorate of Social Work and Child Protection Services Suceava in collaboration with the city halls and social work services from each area. The county authorities' support to the children left at home with their caregivers has materialized in social measures, targeted information campaigns, and even specially designed events for the children, their caregivers from Suceava County, and also for their parents working abroad.

The County Council of Suceava has taken concrete measures to maintain and develop a permanent and coherent relationship with the Romanians working abroad. The impact of the intra-EU migration of the labor force on the county's economy is important. The last decades have witnessed the economic impact of the labor migration phenomenon on Suceava County, from remittances sent to support the families back home to business investments of those who decided to come home. Local authorities are aware of the impact of the labor migration on their county's economy in both positive and negative ways:

'Even if the people who work abroad send money to those that were left at home and we can see the increasing number of new buildings and cars, the supermarkets becoming more crowded, etc., many local employers complain about the lack of workforce. For this reason, efforts must be made, both locally and nationally, to take concrete measures to encourage the return of those who have gone abroad' (Department director, Suceava County Council).

1 Official website of Suceava County Council: http://www.cjsuceava.ro/index.php/ro/relatia-cu-dias pora. 
This is the reason why the Suceava County Council decided to do something more than the national institutions such as The Ministry for Romanians Abroad or The Department for the Relation with Romanians Abroad within the Presidency of Romania. One of the reasons for this is 'the lack of public policies for the diaspora that would contribute to the return of the people from Suceava to their own homes. What we feel from talking to them or their families is that they still do not dare to leave the job abroad and come home permanently' (Department director, Suceava County Council).

The Suceava County Council was the first in Romania to set up a department called 'Relationship with diaspora'. Through the Decision of the County Council no. $117 / 2016$, the new organizational chart of the institution was approved, which includes the 'Diaspora Service' and the development of external partnerships. The aim of the 'Diaspora Service' is to provide a link between the diaspora and various institutions, to solve the specific problems of the persons working abroad. The most important tasks of the diaspora relations office are: the collaboration with the embassies and consulates of Romania in other countries on issues related to the diaspora, especially those concerning the persons from Suceava county who work abroad, the collaboration with the Romanian Diaspora associations and the consulting on the promotion of projects funded by the Ministry for Romanians Abroad, the facilitation of links between the diaspora and the organizational entities responsible for the management of European funds in order to provide information on the opportunities for accessing these funds, the identification of possible business and investment opportunities and their further promotion to the people from Suceava that live abroad, the guidance of people from Suceava County from the diaspora who request access to certain public services, providing assistance and counseling to people in Suceava County residing abroad by conveying information about their socio-professional integration possibilities in Romania. The department has relationships with associations from many countries, such as Ukraine (considered as a part of the historic diaspora), Great Britain, Spain, Italy, Portugal, Germany, Belgium, Austria, Greece, Switzerland, Netherlands, Ireland, Republic of Moldova and Poland. The international partners play a very important role in reaching people interested in organized actions. Some of them are cultural organizations of the diaspora in Vienna, New York, or from Italy and Spain, etc.

For a continuous development of actions and projects proposed by the County Council of Suceava regarding the people from the area that are working abroad, the involvement of different partners, whether local, national or international, is necessary:

'The Prefect Institution - Suceava (Prefectura), the County Register Office Suceava (Direcția Fudețeană de Evidență a Persoanelor), Suceava County House for Pensions (Casa de Pensii Suceava), The Passport Services (Serviciul Pașapoarte), the General Directorate for Social Work and Child Protection 
(DGASPC), the County Agency for Payments and Social Inspection Suceava (Agenția Județeană pentru Plăți și Inspecție Socială), the National Agency for Fiscal Administration Suceava (Agenția Națională pentru Administrare Fiscală), the County Payment Office for Rural Development (Oficiul Județean de Plăți pentru Dezvoltare Rurală), County Library Suceava, the Museum of Bucovina, Bucovina Cultural Center, Ștefan cel Mare Airport Suceava, North East Regional Development Agency, the NGO Save the Children - Suceava, Ștefan cel Mare University of Suceava, the County School Inspectorate Suceava (Inspectoratul Școlar fudețean)' (Department director, Suceava County Council).

On July 26, 2016, a Facebook page named 'Relationship with diaspora' was created; ever since the department has been constantly communicating using this instrument reaching 424 followers in January 2019. A variety of tools have been used: posts, videos, pictures, links with articles from the local media, and even a few lives. The results of a content analysis focusing on topics between May 1, 2018, and January 20, 2019, are presented in Table 1.

Table 1: Facebook posts of the page 'Relationship with diaspora'

\begin{tabular}{lc}
\hline \multicolumn{1}{c}{ The subject of the post } & $\begin{array}{c}\text { No. } \\
\text { of posts }\end{array}$ \\
\hline Information about the activity of The Ministry for Romanians Abroad & 5 \\
\hline Information about applications for financing projects related to the diaspora & 7 \\
Information about the events organized by the County Council Suceava & 23 \\
\hline Information about the airport Suceava (flight schedule, plans of developing the airport) & 8 \\
\hline $\begin{array}{l}\text { Information about meetings of the county representatives } \\
\text { with foreign investors, ambassadors, or other foreign representatives }\end{array}$ & 4 \\
\hline $\begin{array}{l}\text { Programs, events organized for Romanian children living abroad } \\
\text { Programs, events organized for children living in Suceava with parent(s) working abroad }\end{array}$ & 5 \\
\hline $\begin{array}{l}\text { Information about successful citizens from Suceava county, who are living abroad } \\
\text { Information about citizens from Suceava county that returned home }\end{array}$ & 3 \\
\hline $\begin{array}{l}\text { Information about positive aspects of the local economy } \\
\text { (mostly related to the hospitality sector) }\end{array}$ & 5 \\
\hline
\end{tabular}

Source: The authors

Local media plays an important role in promoting the initiatives and the projects of the County Council of Suceava. Press conferences are constantly organized as a means to transmit the most important information. Trying to stay close to all the communities, to promote their events through up-to-date channels of communication, the representatives of the County Council of Suceava choose to promote their various projects through the written press, the official website of the institution, the official Facebook account, and local, regional or national TV or radio stations. Local 
media seems to understand the importance of the topic: 'Most of the time, the messages posted by the County Council of Suceava are taken over by the media, which leads to a better flow of information towards the diaspora' (Department director, Suceava County Council).

The first event organized by the Suceava County Council dedicated exclusively to the diaspora was called 'The Month of Diaspora', which started with the action Diaspora Meeting in Suceava County, organized on the $1^{\text {st }}$ of August 2016, in the Ștefan cel Mare Hall of the Administrative Palace, with the participation of over 150 people, of whom 90 were from the diaspora. In 2018, the third edition of this event took place, debuting on the $28^{\text {th }}$ of July 2018, at the Administrative Palace. 'The Month of Diaspora' event is held annually and the $4^{\text {th }}$ edition was organized in August 2019. This is one of the most important projects of the County Council of Suceava regarding the relationship with the diaspora, but this is followed by other initiatives, such as: creating on-line diaspora communication platforms, promoting tourism in the area for better knowledge and visibility, participating in international fairs to promote Bucovina in several places abroad, including locations with large Romanian communities, promoting, supporting and developing entrepreneurship among people from Suceava County that live abroad and offering support for families with parents working abroad and children left at home.

The issue of children whose parents left to work abroad is a topical one, which needs to be given special importance at both national and local levels, as they represent a category exposed to risks and dangers that may ultimately lead to the violation of their rights. Within the project 'The Month of Diaspora', on August 3, 2018, the County Council invited specialists to talk to the parents who usually work abroad and their children at the Bucovina Library and make them aware of the risks they are exposed to due to their special situation. This was already the third edition of the event called 'The Children of the Romanians from the Diaspora'. Besides the Suceava County Council and the Bucovina Library, The Teaching-staff Resource Centre (Casa Corpului Didactic), The Romanian Orthodox Church and the County Police Department Suceava (Inspectoratul Județean de Poliție) were among the organizers. A wide range of subjects of interest was presented, from the legislation that applies in this situation, children's rights, and parents' obligations to opportunities if they decide to come back home. The public consisted of parents working abroad and their children, teachers, and educators, social workers, members of NGOs working in this field. This event was covered by the local online media ( 3 articles in crainou.ro, obiectivdesuceava.ro, and monitorulsv.ro) and on social media (on the Facebook page 'Relationship with diaspora' and the YouTube Channel of Nest-TV).

According to the Romanian legislation, the General Directorate of Social Work and Child Protection Services Suceava is the main institution involved in monitoring the situation of the children left at home by parent(s) working abroad. The institution developed a strategic action plan concerning these children. First, a guide for the parents working or planning to work abroad was developed and distributed as part 
of a continuous information campaign. The second measure consisted of establishing mobile teams that analyzed the situation of the children and act in the field. Afterward, they developed and organized specific activities for those affected by the labor migration phenomenon.

Through the above-mentioned guide, the authorities try to advise the parents as to what they should do while at least one of them is working abroad. The mother is considered the most important person for young children especially, so, if one of the parents needs to go abroad for work, the advice is that the father should be the one to leave home to work abroad. The legal representation of the minors needs to be ensured according to Law no. 272/2004, art. 105 on the protection and promotion of the rights of the child and the additional Government Decision no. 691/2015 on monitoring children with parents working abroad. While one or both parents are gone, the caregiver should be a person over 18, but not one of the older siblings. The risk that all the children get into social protection services is very high if this is not observed.

According to the information materials of the General Directorate of Social Work and Child Protection Services Suceava, parents working abroad are encouraged to maintain a close relationship with the teachers because they are the first ones that could observe negative emotional states, possible abuse or if the children are neglected. This is a sort of warning system helping to identify children's problems at an early stage. The authorities encourage daily communication between parent(s) and children via phone, e-mail, and/or social media. The emotional stability of children is a very important issue. Parents are not encouraged to send money or expensive gifts directly. The parents' advice regarding trust and honesty regardless of the problems their children face plays an important role in the education and growth of children. Parents are encouraged to work legally to avoid exploitation through illegal work. Taking into consideration that the parents are already working abroad, in the last article of the parents' guide, the authorities insist on parents sending a notification to the local authorities from their hometown by e-mail or fax, in which they mention who is the children's caregiver, thus avoiding risky situations. The General Directorate of Social Work and Child Protection Services Suceava information materials indicate the legal framework of leaving children back home when working abroad. Children's rights in this particular situation are emphasized.

Years before the Romanian legislation implemented mandatory monitoring visits at home to check the situation of the children left at home by the parent(s) working abroad, relevant projects had been developed and conducted in the Suceava County. The mobile team system was implemented at the level of Suceava County in September 2002, through funding from the PHARE program, through the development of partnerships with the County Directorate for the Protection of Children's Rights, the Blijdorp-Belgium Association, Blijdorp-Romania Association, A New Life Foundation, Siret. The 'Recovery' project was implemented, financed, and carried out during 12 months, after which the Suceava County Council took over the system in September 2003. The 'Transfer Skills, Skills Training' Project - an extension of the mobile team 
- represented an extension of the 'Recovery' Project through the setting up of three working points in the following towns: Gura Humorului, Fălticeni and Siret.

Mobile teams have as their primary objective to ensure the transfer of expertise and family-specific knowledge regarding effective methods of recovery, therapy, rehabilitation of children with disabilities, and preschool children with at least one parent working abroad - through social work, psychology, speech therapy, etc. Each mobile team is composed of 5 members: 2 social workers, a psychologist, a speech therapist, and a physical therapist.

Mobile teams carry out information and community-related activities through meetings with local authorities to find the best strategies for informing and raising public awareness of the problems faced by families with children with special needs (with one or both parents working abroad): marginalization, social and school disintegration, not addressing children's disabilities correctly. Mobile teams provide services to children with disabilities (family or foster care) aged between 0-18 and children whose parents are working abroad for ages 3-7. At present, mobile teams are providing services to 125 children with disabilities and 87 children with at least one parent working abroad. The work of the teams is mainly based on networking, communication, setting up working strategies, organizing the team's composition on a case-by-case basis, organizing the daily program of the route, counseling and educating parents, defusing potential conflicts in the community, maintaining contact with the authorities and therapy.

The National Authority for the Protection of Children's Rights has already concluded a protocol with the Office for Labor Migration, whereby each local authority has the obligation to permanently check the situation of children whose parents are going to work abroad. As the check can only be done for those who are legal residents, the data obtained cannot accurately reflect reality, but only a small part of the problem, because in 2018 there were still some parents who went abroad to work without contracts even after the law was changed. The problem faced by these projects is the insufficient number of social assistants, taking into consideration the complexity of their work in this region. This is a problem, especially in rural areas.

The dialogue between the representatives of the diaspora and local public administration representatives from Suceava contributes to the identification of specific problems that they or their children left at home are facing. Starting from the issues discussed during those meetings, some of them during 'The Month of Diaspora' project, the Suceava County Center for Resource and Educational Assistance, an institution financed by the Suceava County Council, has proposed the initiation of a project of on-line psycho-pedagogical and psychological counseling of the parents from Suceava who are working abroad. The issues that the authorities intend to address through this project are parent-child communication problems, child-teacher problems, parent-child-teacher problems, attachment problems, emotional difficulties, and specific learning disabilities. The first step to getting assistance is filling out an online form available on the website of the County Council of Suceava. Then, 
a date is set for counseling, and the actual on-line counseling, up to ten counseling sessions, follows.

The General Directorate of Social Work and Child Protection Services Suceava also organized a special event for parents that work abroad, for teachers and social assistants and NGOs dealing with children in this situation at Gura Humorului on August 10, 2018, during 'The Month of Diaspora'.

\section{Conclusions and future outlook for policy makers}

Summarizing our findings, we can emphasize that the Suceava County Council developed a defined strategy to deal with the negative effects of the labor migration phenomenon. The initiative to develop a Diaspora Department, the first of its kind in Romania, a structure that communicates with other actors in the local public administration to solve the specific problems of the labor migrants from Suceava and has developed new projects and communication strategies to attract people working abroad back home, to invest in their communities and to reunite with their families, has already had positive effects. The special issue of children left at home by the parent(s) working abroad was included in the agenda of the Suceava Country Council through the Diaspora Department. The County Council Suceava successfully acted as a networking agent by organizing events such as debates, workshops, or round tables on this topic. The media coverage of the event increased the awareness of the issue, informed parents working abroad about their legal obligations, and about the risks of their actions regarding their family life. Moreover, partnerships with civil society institutions were initiated and common activities were conducted which is in line with the multi-level model governance model (van Ostaijen and Scholten, 2018). Local authorities combined in their strategies and throughout their activities socio-economic and cultural aspects recommended by scholars (Alexander, 2007) for a successful approach.

Our interviews revealed a need for the improvement of the legal framework and better cooperation between the Ministry of Romanians Abroad and the local authorities from regions with a large number of labor migrants. More social measures are still needed. In the majority of cases, the economic situation of the children left at home is not bad. Additional programs in schools or other educational institutions are much more effective in dealing with the (potential) negative effects of their situation. This is the reason why social policies should be developed together with teachers and education specialists. Closer cooperation with NGOs working in the field is also recommended.

Regarding Child Protective Services Suceava, they are also making efforts to support the children left at home through different projects. The mobile teams are undersized, according to the representatives of the institution, and they are making efforts to increase their number. They are the ones that observe, counsel, and try to find solutions to the problems in the territory. Increasing the number of social assistants especially in rural areas will have a positive effect on dealing with this complex issue. 
The implications of our study are relevant not only for Romania, where some of the practices of Suceava country dealing with the children left at home and trying to build strong ties with the diaspora can be applied. Some of the practices can be used also in other Eastern European countries facing intra-EU migration of labor force such as Bulgaria and Poland.

As it is based on a qualitative methodology, the present research has its limits and the results cannot be generalized. This research revealed the perspective of the county policymakers and policy implementers. We focused especially on the County Council and the General Directorate of Social Work and Child Protection Services Suceava. Future research revealing the perspective of the parents working abroad, of the caregivers at home, and the teachers and educators can contribute to a better understanding of the needs of the children and can contribute to more effective public policies.

\section{References:}

1. Alexander, M., Cities and Labour Immigration: Comparing Policy Responses in Amsterdam, Paris, Rome and Tel Aviv, Aldershot: Ashgate, 2007.

2. Ban, C., 'Economic Transnationalism and Its Ambiguities: The Case of Romanian Migration to Italy', 2012, International Migration, vol. 50, no. 6, pp. 129-149.

3. Bertoli, S., Brücker, H. and Moraga, J.F.-H., 'The European Crisis and Migration to Germany: Expectations and the Diversion of Migration Flows', 2013, IZA DP no. 7170, [Online] available at http://ftp.iza.org/dp7170.pdf, accessed on October 15, 2018.

4. Bleauhu, A., 'With Calluses on Your Palms They Don't Bother You: Illegal Romanian Migrants in Italy', 2007, Focaal - European fournal of Anthropology, vol. 49, pp. 101-109.

5. Cassarino, J.-P., 'Theorising Return Migration: The Conceptual Approach to Return Migrants Revisited', 2004, International fournal on Multicultural Societies, vol. 6, no. 2, pp. 253-279.

6. Ciornei, I., 'European Mobility and Local Political Incorporation: The Case of British and Romanian Residents in Spain', 2016, Migration Studies, vol. 4, no. 1, pp. 38-58.

7. Diaspora Suceava Relations, [Online] available at http://www.cjsuceava.ro/index.php/ro/ relatia-cu-diaspora, accessed on January 15, 2019.

8. Digi24, 'Date oficiale. Peste 18.000 de copii au ambii părinți plecați la muncă în străinătate' [Official Data. More than 18,000 Children Have Both Parents Gone to Work Abroad], 2017, [Online] available at http://www.digi24.ro/stiri/actualitate/social/date-oficiale-peste-18000-de-copii-au-ambii-parintii-plecati-la-munca-in-strainatate-835674, accessed on October 10, 2018.

9. Diminescu, D., 'Exerciţiul dificil al liberei circulaţii: o introducere în istoria migraţiei recente a românilor' [The Difficult Exercise of Free Movement: An Introduction to the History of Recent Migration of Romanians], in Anghel, R.G. and Horvath, I. (eds.), Sociologia migrației. Teorii şi studii de caz româneşti [Sociology of Migration. Romanian Theories and Case Studies], Iaşi: Polirom, 2009, pp. 45-64.

10. Eisenstadt, S.N., 'Analysis of Patterns of Immigration and Absorption of Immigrants', 1953, Population Studies, vol. 7, no. 2, pp. 167-180. 
11. Engler, M. and Weinmann, M., 'EU-Migration nach Deutschland: Aktuelle Trends', Paris: Französische Institut für Internationale Beziehungen, 2015, [Online] available at http:// www.ifri.org/sites/default/files/atoms/files/ndc_121_engler_weinmann_de_0.pdf, accessed on October 15, 2018.

12. Eurostat, 'Population on January $1^{\text {st }}$ by Age Group, Sex, and Country of Birth', 2017, [Online] available at http://appsso.eurostat.ec.europa.eu/nui/show.do?dataset=migr_pop 3ctb\&lang=en, accessed on October 20, 2018.

13. General Directorate of Social Work and Child Protection Services, [Online] available at http://www.dpcsv.ro/ro/, accessed on January 15, 2019.

14. Hanganu, E., Humpert, S. and Kohls, M., Zuwanderung aus den neuen EU-Mitgliedstaaten Bulgarien und Rumänien, Bundesamt für Migration und Flüchtlinge, 2014.

15. Jobelius, M. and Stolciu, V., Die Mär vom »Sozialtourismus« Zuwanderung rumänischer Staatsbürger nach Deutschland und in andere EU-Mitgliedsländer, Berlin: Friedrich Ebert Stiftung, 2014, [Online] available at http://library.fes.de/pdf-files/id-moe/10467.pdf, accessed on October 1, 2020.

16. Kindler, M., 'Poland's Perspective on the Intra-European Movement of Poles. Implications and Governance Responses', in van Ostaijen, M. and Scholten, P. (eds.), Between Mobility and Migration: The Consequences and Governance of Intra-European Movement, Springer, 2018, pp. 183-204.

17. Levitt, P., 'Social Remittances. Migration Driven Local-Level Forms of Cultural Diffusion', 1998, International Migration Review, vol. 32, no. 4, pp. 926-948.

18. Lodigialini, E., 'The Effect of Emigration on Home-country Political Institutions', IZA World of Labor, 2016, [Online] available at https://wol.iza.org/articles/effect-of-emigrationon-home-country-political-institutions/long, accessed on October 1, 2020.

19. Lulle, A., Krisjane, Z. and Bauls, A., 'Diverse Return Mobilities and Evolving Identities among Returnees in Latvia, Social Remittances and Influence on Communities of Origin', in Anghel, R., Fauser, M. and Boccagni, P. (eds.), Transnational Return and Social Change. Hierarchies, Identities and Ideas, Wimbledon: Athem Press, 2019, pp. 103-122.

20. Mara, I., 'Surveying Romanian Migrants in Italy before and after the EU Accession: Migration Plans, Labor Market Features, and Social Inclusion', 2012, Norface Migration Discussion Paper no. 2012-24, [Online] available at http://ww.norface-migration.org/publ_ uploads/NDP_24_12.pdf, accessed on October 23, 2018.

21. Marcu, S., 'Romanian Migration to the Community of Madrid (Spain): Patterns of Mobility and Return', 2011, International fournal of Population Research, vol. 2011, pp. 1-13.

22. OECD, International Migration Outlook Report, 2018, [Online] available at http://www. oecd.org/migration/international-migration-outlook-1999124x.htm, accessed on January 10, 2019.

23. Pawlak, M., 'Research-policy Dialogues in Poland', in Scholten, P., Entzinger, H., Penninx, R. and Verbeek, R. (eds.), Integrating Immigrants in Europe: Research-policy Dialogues, Dordrecht: Springer, 2015, pp. 253-274.

24. Peixoto, J., 'The International Mobility of Highly Skilled Workers in Transnational Corporations: The Macro and Micro Factors of the Organizational Migration of Cadre', 2001, International Migration Review, vol. 35, no. 4, pp. 1030-1053. 
25. Popescu, T., 'Immigration Discourses: The Case of Romanian Immigrants in Italy', 2008, Fournal of Linguistic and Intercultural Education, vol. 1, pp. 31-44.

26. Relationship with Diaspora, [Online] available at www.facebook.com, accessed on January $15,2019$.

27. Ricci, A., 'Romanians in Italy: The Largest Diaspora Community', in Pittau, F. (ed.), The Other Side of Italy: Immigration in a Changing Country, Rome, Italy: Centro Studi e Ricerche IDOS, 2015, pp. 39-59.

28. Romanian Presidency, [Online] available at www.presidency.ro, accessed on October 15, 2018.

29. Saghin, D., Lucheș, D. and Marici, M., 'The Influence of Personal and Professional Variables Upon the Nature of Immigration of Romanian Doctors to France: The Moderating Effect of Gender', 2016, Transylvanian Review of Administrative Sciences, vol. 49E, pp. 132-149.

30. Sandu D., 'Migraţia de revenire ca proiect şi stare de spirit. Introducere' [Return Migration as a Project and Mood. Introduction], in Sandu, D. (ed.), Comunităţi româneşti în Spania [Romanian Communities in Spain], Bucureşti: Open Society Foundation, 2009, pp. 43-68.

31. Sandu D., Lumile sociale ale migratiei românești în străinătate [The Social Worlds of Romanian Migration Abroad], Iaşi: Polirom, 2010.

32. Sandu, D., 'Străinătatea în mentalitățile urbane' [Foreignness in Urban Mentalities], in Sandu, D. (ed.), Viața socială în România urbană [Social Life in Urban Romania], Iași: Polirom, 2006, pp. 19-54.

33. Șerban, M. and Voicu, B., 'Romanian Migrants to Spain: In-or Outside the Migration Networks-A Matter of Time', 2010, Revue d'études comparatives Est-Ouest, no. 41, pp. 97-124.

34. Stanek, M., 'Patterns of Romanian and Bulgarian Migration to Spain', 2009, Europe-Asia Studies, vol. 61, no. 9, pp. 1627-1644.

35. van Ostaijen, M. and Scholten, P., 'Between Mobility and Migration: The Consequences and Governance of Intra-European Movement', in van Ostaijen, M. and Scholten, P. (eds.), Between Mobility and Migration: The Consequences and Governance of Intra-European Movement, Springer, 2018, pp. 1-20.

36. Vasile, V., 'Labour Mobility Impact on Sending Countries. Romanian EU Workers Case Study', 2014, Procedia Economics and Finance, vol. 8, pp. 737-746.

37. Vasile, V., Boboc, C., Pisica, S. and Cramarenco, R.E., 'Estimarea impactului liberei circulaţii a lucrătorilor români pe teritoriul UE, începând cu 01.01.2014; realităţi şi tendinţe din perspectivă economică, ocupaţională şi socială, la nivel naţional şi european' [Estimating the Impact of the Free Movement of Romanian Workers on the EU Territory, Starting with 01.01.2014; Realities and Trends from an Economic, Occupational and Social Perspective, at National and European Level], Strategy and Policy Studies Series no. 3/2013, [Online] available at https://www.econstor.eu/handle/10419/141817, accessed on January 15, 2019.

38. Vîrgă, D. and Iliescu, D., 'The Well-being of Romanian Workers in Spain: Antecedents and Moderators', 2017, European fournal of Work and Organizational Psychology, vol. 26, no. 1, pp. 149-159.

39. White, A., 'Polish Returnees' Livelihood Strategies, Social Remittances and Influence on Communities of Origin', in Anghel, R., Fauser, M. and Boccagni, P. (eds.), Transnational Return and Social Change. Hierarchies, Identities and Ideas, Wimbledon: Athem Press, 2019, pp. 103-122. 